\title{
Pengembangan $E$-Modul Berbantuan $Q R$ Code pada Pembelajaran Daring Mata Pelajaran Biologi Materi Sel Kelas XI MIA
}

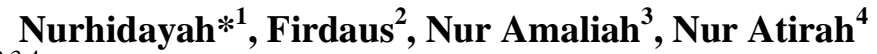 \\ 1,2,3,4 Pendidikan Biologi, FKIP, Universitas Sulawesi Barat

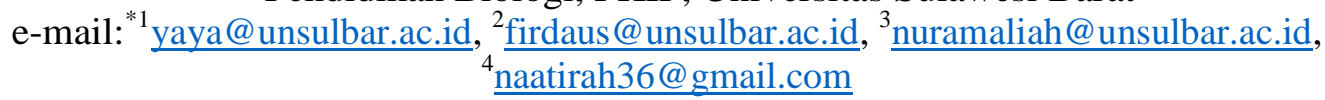

\begin{abstract}
Abstrak
Jenis penelitian ini adalah penelitian dan pengembangan $(R \& D)$ yang bertujuan untuk menghasilkan e-modul berbantuan $Q R$ code sebagai bahan ajar pada pembelajaran daring mata pembelajaran biologi materi sel yang valid, praktis dan efektif. Pengembangan dilakukan dengan menggunakan model ADDIE yang terdiri dari: analysis, design, development, implementation dan evaluation. Subjek penelitian ini adalah XI MIA 2 MAN 1 Majene. Data dikumpulkan dengan observasi, wawancara, angket dan tes. Hasil penelitian: (1) validasi instrumen yang telah dibuat dari segi angket ahli 92\%, angket kepraktisan 92\% dan tes hasil belajar 0.975 merupakan kategori sangat valid sedangkan emodul berbantuan QR code dari segi ahli materi 90\%, dan dari segi ahli media 90\% merupakan kategori sangat valid. (2) Kepraktisan e-modul berbantuan QR Code berdasarkan respon guru $96 \%$ dan respon peserta didik $87 \%$ merupakan kategori sangat praktis. (3) Keefektifan e-modul berbantuan QR Code berdasarkan tes hasil belajar peserta didik adalah $68.75 \%$ merupakan kategori efektif. Jadi dapat disimpulkan bahwa e-modul berbantuan QR code telah memenuhi kategori valid, praktis dan efektif.
\end{abstract}

Kata Kunci: Bahan Ajar, E-Modul, QR Code

\section{PENDAHULUAN}

Bahan ajar yang baik adalah bahan ajar yang disesuaikan dengan kemampuan dan lingkungan peserta didik. Peserta didik dapat mempelajari suatu materi secara sistematis menggunakan bahan ajar yang baik sehingga materi pelajaran dapat dipahami secara utuh. Salah satu jenis bahan ajar adalah modul (Febrianti, 2017, p. 4). Modul merupakan bahan ajar yang disusun secara sistematis dan menarik yang mencangkup tujuan pembelajaran, isi materi dan evaluasi yang dapat digunakan secara mandiri. Modul dapat diartikan sebagai materi pelajaran yang disusun dan disajikan secara tertulis sedemikian rupa sehingga pembacanya diharapkan dapat menyerap sendiri materi tersebut (Daryanto, 2013, p. 31). Namun, peserta didik zaman sekarang sangat antusias dengan segala sesuatu yang berbau teknologi modern, hal ini dapat dimanfaatkan untuk membuat bahan ajar seperti modul elektronik (e-modul).

E-modul merupakan bahan ajar mandiri yang disusun secara sistematis yang dalam penggunaannya menggunakan media elektronik. Pembelajaran dapat berlangsung secara efektif karena e-modul dapat membantu peserta didik yang mengalami kesulitan dalam belajar (Wulansari et al., 2018). Tetapi, penggunaan $e$-modul pembelajaran dalam proses pembelajaran memiliki beberapa kelemahan seperti $e$ modul yang didesain secara kaku dan tidak bervariasi. Oleh sebab itu, e-modul dilengkapi dengan penggunaan multimedia sebagai usaha untuk menggugah minat belajar peserta didik, apalagi akhir-akhir ini peserta didik lebih banyak menyukai dunia teknologi dibandingkan belajar secara konvensional (Budiono \& Susanto, 2006).

Seiring dengan perkembangan kebutuhan informasi, muncul sebuah quick respone code untuk memudahkan dalam mengakses informasi. $Q R$ code merupakan evolusi dari barcode yang awalnya satu dimensi menjadi dua dimensi (Mustakim et al., 2013). Tujuan utama $Q R$ Code digunakan untuk memudahkan pengguna smartphone mengakses informasi dengan dua cara, (1) scan QR Code, (2) membuka browser, browser langsung menghubungkan ke youtube atau web. Apalagi, aplikasi QR Code Scanner untuk berbagai macam tipe ponsel cukup banyak tersedia untuk diunduh melalui internet.

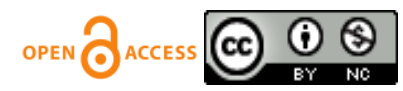


Menurut hasil penelitian Saleh et al. (2018), di Universitas Negeri Makassar tahun 2018 pada mahasiswa jurusan bahasa asing, menunjukkan bahwa motivasi belajar menggunakan $Q R$ Code meningkat. Selain motivasi belajar, ternyata $Q R$ Code juga mempengaruhi hasil belajar. Hasil penelitian Mustakim et al. (2013) di SMA Labschool UNTAD tahun 2013 pada kelas X, menunjukkan bahwa hasil belajar peserta didik yang mendapat pembelajaran dengan $Q R$ Code lebih baik dari hasil belajar peserta didik yang mendapat pembelajaran konvensional.

Hasil penelitian tersebut sesuai pendapat (Lee dalam Ataji et al., 2019), yang menyatakan bahwa menggunakan $Q R$ Code dan smartphone yang diterapkan di kelas dapat memberikan keuntungan yang banyak seperti buku panduan bergambar dan mudah digunakan sesuai untuk tingkat peserta didiknya. Selain itu, smartphone dapat digunakan untuk membuka bahan ajar elektronik. Apalagi saat ini wabah corona virus disease 2019 (covid-19) telah melanda Indonesia sehingga berdampak juga bagi dunia pendidikan yang mengakibatkan sekolah diberbtutup dan diterapkan pembelajaran secara daring.

Berdasarkan hasil wawancara dengan guru biologi Madrasah Aliah Negeri 1 Majene, diperoleh informasi bahwa bahan ajar yang digunakan dalam pembelajaran daring yaitu $e$-modul dan e-LKPD yang diberikan melalui google classroom. Tetapi, e-modul yang digunakan dalam kegiatan pembelajaran belum sesuai dengan kerangka modul. Menurut Daryanto (2013,p.25), kerangka modul tersusun atas sampul, kata pengantar, daftar isi, petunjuk penggunaan modul, tujuan pembelajaran, peta materi, materi pokok, rangkuman, evaluasi, kunci jawaban, daftar pustaka dan glosarium. Selain itu, terdapat beberapa kelemahan dalam e-modul tersebut yaitu isi materi yang susunannya kurang rapi. Sehingga, peserta didik akan mengalami kesulitan dalam memahami isi materi dan menimbulkan rasa kebosanan serta kurangnya perhatian terhadap pelajaran yang sedang dihadapi. Hal ini salah satu penyebab menurunnya motivasi belajar dan hasil belajar peserta didik.

Untuk meningkatkan motivasi belajar dan hasil belajar peserta didik maka peneliti mengembangkan bahan ajar berupa $e$-modul dengan berbantuan $Q R$ Code. $E$-modul pembelajaran disajikan dalam bentuk elektronik, sehingga memudahkan peserta didik untuk belajar setiap saat selama pembelajaran daring. Selain itu, $e$-modul yang akan dikembangkan oleh peneliti yaitu menampilkan ilustrasi gambar yang menarik dan sesuai dengan materi yang dipelajari dan isi $e$-modul yang akan dikembangkan oleh peneliti disesuaikan dengan KI dan KD, sehingga akan memudahkan dalam mencapai tujuan pembelajaran yang telah ditetapkan. Meskipun, beberapa penelitian sebelumnya sudah menggunakan $Q R$ Code dalam kegiatan pembelajaran, namun belum digunakan dalam penggunaan $e$-modul. Olehnya, penelitian ini bertujuan untuk mengetahui kevalidan, kepraktisan dan keefektifan $e$-modul berbantuan $Q R$ code pada pembelajaran daring mata pelajaran biologi materi sel kelas XI MIA MAN 1 Majene.

\section{METODE PENELITIAN}

Jenis penelitian ini merupakan jenis penelitian dan pengembangan (Research and Development) dengan menggunakan model ADDIE yang terdiri atas analisis (analysis), desain/perancangan (design), pengembangan (development), implementasi/penerapan (implementation) dan evaluasi/umpan balik (evaluation) (Sari, 2017). Produk yang dihasilkan dari penelitian ini berupa $e$-modul berbantuan QR code. Penelitian ini dimulai pada tanggal 24 Agustus 2020 sampai 9 November 2020 dilaksanakan secara online. Subjek penelitian adalah kelas XI MIA 2 sebanyak 16 peserta didik dan 1 guru mata pelajaran Biologi kelas XI MIA MAN 1 Majene. Instrumen yang digunakan dalam penelitian ini, antara lain: (1) lembar validasi angket ahli, lembar validasi angket kepraktisan dan lembar validasi $e$-modul berbantuan $Q R$ code untuk ahli materi dan ahli media; (2) angket respon guru dan angket respon peserta didik digunakan untuk memperoleh data mengenai respon guru dan peserta didik terhadap penggunaan bahan ajar $e$-modul berbantuan $Q R$ code, dan; (3) tes hasil belajar kognitif yaitu alat yang digunakan peneliti untuk mengukur penguasaan peserta didik terhadap materi yang telah diajarkan oleh guru dan mengukur perkembangan kemajuan belajar peserta didik. Analisis data validasi dan kepraktisan dapat dihitung dengan menggunakan rumus (Centaury, 2015).

Keterangan:

$$
\mathrm{P}=\frac{f}{N} x 100 \%
$$

$\mathrm{P}=$ Persentase nilai validasi/kepraktisan 
$f=$ Perolehan skor

$N=$ Skor maksimum

Kategori validasi terhadap ahli materi dan media berdasarkan nilai akhir dapat dilihat pada tabel $1 \mathrm{di}$ bawah ini (Centaury, 2015).

Tabel 1 Skala Tingkat Penilaian Validator

\begin{tabular}{cc}
\hline Nilai & Keterangan \\
\hline $81-100$ & Sangat valid/praktis \\
$61-80$ & valid/praktis \\
$41-60$ & Kurang valid/praktis \\
$21-40$ & Tidak valid/praktis \\
& Sangat tidak \\
$0-20$ & valid/praktis \\
\hline
\end{tabular}

Analisis keefektifan $e$-modul berbantuan $Q R$ code menggunakan tes hasil belajar. Ketuntasan hasil belajar peserta didik didasarkan pada kriteria ketuntasan minimum (KKM) yang telah ditetapkan oleh pihak sekolah. Peserta didik dikatakan berhasil dalam belajar jika memperoleh nilai minimal 75. Menurut Indraningtias \& Wijaya (2017), untuk mengetahui keefektifan e-modul berbantuan $Q R$ code yang dikembangkan dapat dihitung dengan menggunakan rumus:

Keterangan:

$$
\mathrm{P}=\frac{x}{y} \times 100 \%
$$

P: Presentasi peserta didik yang tuntas

$\mathrm{x}$ : Banyak peserta didik yang tuntas

y: Jumlah seluruh peserta didik

Hasil presentasi yang diperoleh setelah melakukan perhitungan dengan menggunakan rumus tersebut kemudian disesuaikan dengan kriteria kualifikasi penilaian berdasarkan Arikunto (2010, p. 26) yang ditunjukkan pada tabel 2 berikut.

Tabel 2 Kriteria Keefektifan Tes Hasil Belajar

\begin{tabular}{cc}
\hline Persentase Ketuntasan & Kriteria \\
\hline $81-100$ & Sangat efektif \\
\hline $61-80$ & Efektif \\
\hline $41-60$ & Cukup efektif \\
\hline $21-40$ & Kurang efektif \\
\hline $0-20$ & Tidak efektif \\
\hline
\end{tabular}

\section{HASIL DAN PEMBAHASAN}

Hasil yang diperoleh dari penelitian dan pengembangan ini adalah e-modul berbantuan $Q R$ Code yang telah memenuhi kriteria valid, praktis dan efektif. Adapun hasil analisis validasi yang diperoleh dapat diuraikan sebagai berikut.

Tabel 3. Hasil Uji Validasi Oleh Ahli

\begin{tabular}{lll}
\hline Aspek & Hasil penilaian & Keterangan \\
\hline Ahli materi & $90 \%$ & Sangat valid \\
\hline Ahli media & $90 \%$ & Sangat valid \\
\hline
\end{tabular}


Validasi E-Modul berbantuan $Q R$ Code dilakukan oleh tiga orang ahli bertujuan untuk menilai validasi bahan ajar dari segi aspek materi dan media. Hal ini dilakukan untuk menguji apakah materi dan media tersebut sudah layak digunakan atau tidak dalam pembelajaran. Nilai rata-rata hasil penilaian yang diperoleh dari ahli berada pada rentang nilai 81-100 dengan nilai validasi masing-masing ahli materi dan ahli media adalah $90 \%$ yang dikategorikan sangat valid dari ketiga validator.

Tabel 4. Hasil Uji Kepraktisan

\begin{tabular}{lcl}
\hline Kriteria Kepraktisan & Persentase (\%) & Kategori \\
\hline Respon guru & $96 \%$ & Sangat Praktis \\
Respon peserta didik & $87 \%$ & Sangat Praktis \\
\hline
\end{tabular}

Angket respon guru dan peserta didik digunakan untuk menilai aspek pembelajaran, bahasa, penyajian, tampilan gambar dan video. Angket respon guru ini diberikan kepada guru biologi MAN 1 Majene dan angket respon peserta didik diberikan kepada peserta didik kelas XI MIA 2 MAN 1 Majene sebanyak 16 orang. Pemberian angket ini bertujuan untuk memperoleh data mengenai respon guru peserta didik terhadap $e$-modul berbantuan $Q R$ Code yang telah dikembangkan oleh peneliti.

Berdasarkan nilai rata-rata total yang diperoleh dari guru biologi berada pada rentang skor $81-100 \%$ dengan nilai P (Persentase skor) adalah $96 \%$ yang dikategorikan sangat praktis atau $e$-modul berbantuan $Q R$ Code yang dikembangkan layak untuk digunakan sedangkan hasil perhitungan keseluruhan angket respon peserta didik nilai rata-rata totalnya adalah $87 \%$. Perolehan skor tersebut berada pada rentang skor $81-100 \%$ yang dikategorikan sangat praktis, artinya $e$-modul berbantuan $Q R$ Code baik digunakan dalam pembelajaran biologi.

Tabel 5. Hasil Uji Keefektifan

\begin{tabular}{lcl}
\hline Kriteria & Persentase (\%) & Kategori \\
\hline Keefektifan & $68.75 \%$ & Efektif \\
\hline
\end{tabular}

Uji keefektifan diukur menggunakan tes hasil belajar setelah materi selesai. Ketuntasan hasil belajar peserta didik didasarkan pada kriteria ketuntasan minimum (KKM) yang telah ditetapkan oleh pihak sekolah MAN 1 Majene. Peserta didik dikatakan tuntas dalam belajar jika memperoleh nilai minimal 75. Berdasarkan tes hasil belajar peserta didik yang telah dilakukan di kelas XI MIA 2 yaitu sebanyak 11 orang memiliki nilai rata-rata $\leq 75$ dari 16 jumlah peserta didik. Jika dipersentasikan maka berada pada rentang skor 61-80 dengan nilai 68.75\% yang dikategorikan efektif atau e-modul berbantuan $Q R$ Code yang dikembangkan efektif digunakan dalam proses pembelajaran dikelas.

Menurut Widodo (2006) suatu produk dapat dikatakan valid apabila memberikan hasil ukur yang sesuai dengan maksud dilakukannya pengukuran tersebut. Dalam hal ini, validasi $e$-modul berbantuan $Q R$ code telah memberikan hasil ukur yang sesuai berdasarkan hasil penilaian dari ketiga validator dengan memperoleh kriteria sangat valid sehingga layak untuk uji coba, lebih lanjut dijelaskan oleh Seruni et al. (2019), yang mengatakan bahwa cara menilai tingkat validasi bahan ajar digunakan lembar validasi ahli materi dan ahli media dengan menggunakan saran para validator.

Hasil analisis validitas bahan ajar sesuai pada tabel 3 yang memperoleh nilai rata-rata validasi ahli materi dan media yaitu 90\% yang artinya bahan ajar yang dikembangkan telah memenuhi kriteria sangat valid. Adapun masukan dan saran yang diberikan oleh validator selama proses validasi, diantaranya (1) terkait kesalahan penulisan, (2) kesalahan penempatan keterangan pada gambar dan tabel, (3) menghapus link video yang ditampilkan karena telah digantikan oleh QR code agar fungsinya tidak ganda, dan (4) menentukan tingkat kognitif pada soal yang dilampirkan. Penilaian suatu bahan ajar dikatakan valid menurut Wulansari et al. (2018) jika memenuhi kriteria, yaitu: (1) validator memberikan penilaian tergolong baik atau sangat baik (2) validator memilih pilihan layak digunakan tanpa revisi atau layak digunakan dengan revisi (3) indikator/deskriptor yang terdapat pada lembar validasi bahan ajar yang telah dikembangkan dengan 
memperhatikan aspek-aspek yang harus diamati dalam menentukan validasi bahan ajar yaitu lembar validasi ahli materi dan lembar validasi ahli media.

Berdasarkan hasil analisis kepraktisan $e$-modul berbantuan $Q R$ code menunjukkan nilai rata-rata total hasil penilaian kepraktisan dari respon guru dan respon peserta didik sebesar $96 \%$ dan $87 \%$. Kedua nilai ratarata tersebut berada pada rentang skor (81-100\%) yang artinya $e$-modul berbantuan $Q R$ code telah memenuhi kriteria sangat praktis. Meskipun $Q R$ code menggunakan minimal 2 gadget atau 1 laptop dan 1 smartphone. Berdasarkan komentar salah satu peserta didik pada angket respon peserta didik yang mengatakan bahwa $e$ modul berbantuan $Q R$ code yang diuji cobakan sudah baik dan bagus, penjelasan yang ada di video menambah pengetahuan mengenai pembelajaran sel dan videonya mudah dipahami serta baru mendapatkan bahan ajar yang menggunakan e-modul berbantuan $Q R$ code.

Menurut Fitria et al. (2017) produk hasil pengembangan dikatakan praktis jika (1) produk yang telah dikembangkan dapat diterapkan di lapangan; (2) responden tertarik menggunakan produk dalam pembelajaran dan (3) responden mudah memahami materi pembelajaran. Adapun langkah-langkah yang ditempuh dalam menganalisis data yang diperoleh yaitu sebagai berikut: (1) menghitung penilaian responden kemudian menghitung jumlah persentasinya; (2) persentase responden yang memberi respon minimal $61 \%$ yang menyatakan produk praktis.

Tingkat keefektifan e-modul berbantuan $Q R$ code diukur dengan menggunakan tes hasil belajar dalam bentuk pilihan ganda. Hasil belajar peserta didik diketahui bahwa dari 16 jumlah peserta didik yang hadir, 11 orang dikatakan tuntas secara individual dan 5 orang dikatakan belum tuntas secara individual. Lima peserta didik yang belum mencapai ketuntasan dikarenakan memperoleh skor hasil belajar di bawah nilai KKM yang telah ditetapkan oleh sekolah yaitu 75 .

Berdasarkan hasil perhitungan analisis hasil belajar peserta didik yang mencapai ketuntasan adalah $68.75 \%$. Perolehan analisis tersebut berada pada rentang nilai 61-80 yang termasuk kategori efektif. Bahan ajar yang dikembangkan dapat dikatakan efektif karena pada pelaksanaannya terdapat hal-hal yang mendukung tercapainya tujuan penelitian antara lain: (1) bahan ajar yang dikembangkan disesuaikan dengan kurikulum 2013; (2) pembelajaran yang menggunakan e-modul berbantuan $Q R$ code menggunakan bahasa yang sederhana, mudah dimengerti agar memudahkan peserta didik dalam memahami materi dengan mudah; (3) penggunaan e-modul berbantuan $Q R$ code membantu peserta didik belajar secara mandiri di rumah selama pembelajaran daring dan peserta didik dapat belajar setiap saat karena $e$-modul dengan berbantuan $Q R$ code disajikan dalam bentuk elektronik.

Hasil tampilan e-modul berbantuan $Q R$ code yang dihasilkan dapat dilihat pada gambar 1, gambar 2, gambar 3 dan gambar 4

Gambar 1 Sampul E-modul




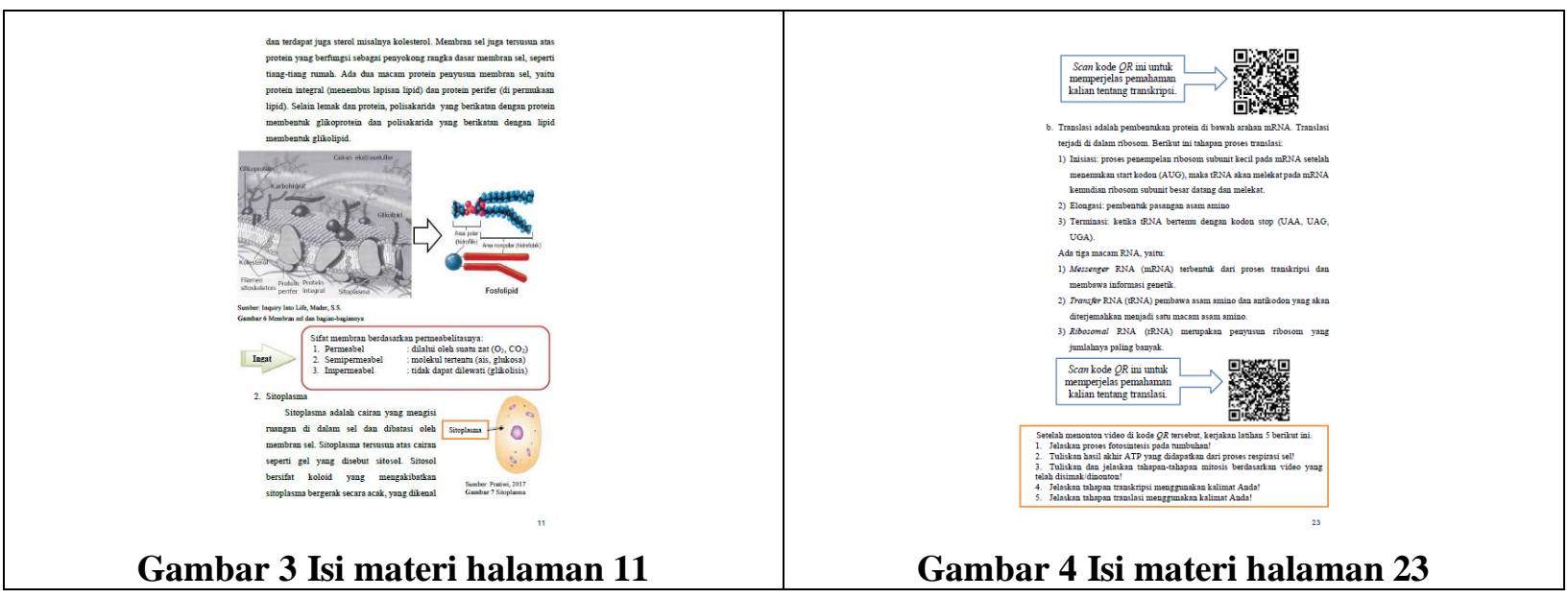

\section{KESIMPULAN}

Berdasarkan hasil penelitian dan pengembangan E-Modul berbantuan $Q R$ Code maka diperoleh kesimpulan bahwa E-Modul berbantuan $Q R$ Code mata pelajaran biologi materi sel yang dikembangkan sudah valid, praktis dan efektif digunakan di kelas XI MIA MAN 1 Majene.

\section{DAFTAR PUSTAKA}

Arikunto, S. 2010. Prosedur Penelitian Suatu Pendekatan Praktik. Rineka Cipta.

Ataji, Hafis M.K., Sutanto, A., \& Lepiyanto, A. (2019). Pengembangan Modul Berbasis QR Code Technology pada Materi Sistem Reproduksi Manusia dengan Terintegrasi Kepada Al-qur'an dan Hadits sebagai Sumber Belajar Biologi Kelas XI MAN 1 Punggur. Biodusiana: Jurnal Pendidikan Biologi, 4 (1), 17-24.

Budiono, E., \& Susanto, H. (2006). Penyusunan dan penggunaan modul pembelajaran berdasar kurikulum berbasis kompetensi sub pokok bahasan analisa kuantitatif untuk soal-soal dinamika sederhana pada kelas X semester I SMA. Jurnal Pendidikan Fisika Indonesia, 4(2), 79-87.

Centaury, B. (2015). Pengembangan perangkat Pembelajaran Fisika Berbasis Inkuiri Padamateri Alat Optik Dan Indikator Dampak terhadap kompetensi Peserta didik Kelas X Sma. Jurnal Riset Fisika Edukasi dan Sains, 1(2), 80-91.

Daryanto. (2013). Menyusun Modul Bahan Ajar Untuk Persiapan Guru dalam Mengajar. Gava Media.

Febrianti, A. F. (2017). Pengembangan Modul Biologi Berbasis Web untuk Mendukung Pembelajaran Interaktif. (Skripsi, Universitas Islam Negeri Raden Intan).

Fitria, A. D., Mustakim, K. M., \& Taufiq, A. U. (2017). Pengembangan Media Gambar Berbasis Potensi Lokal pada Pembelajaran Materi Keanekaragaman Hayati di Kelas X SMAN 1 Pitu Riase Kab. Sidenreng Rappang (Doctoral dissertation, Universitas Islam Negeri Alauddin Makassar).

Indraningtias, D. A., \& Wijaya, A. (2017). Pengembangan Perangkat Pembelajaran Berbasis Pendekatan Matematika Realistik Materi Bangun Ruang Sisi Datar Berorientasi pada Kemampuan Berpikir Kritis Peserta didik Kelas VIII SMP. Jurnal Pendidikan Matematika-S1, 6(5), 24-36.

Mustakim, S., Walanda, D. K., \& Gonggo, S. T. (2013). Penggunaan QR Code Dalam Pembelajaran Pokok Bahasan Sistem Periodik Unsur Pada Kelas X SMA Labschool UNTAD. Jurnal Akademika Kimia, 2(4), 215-221.

Saleh, N., Saud, S., \& Asnur, M. N. A. (2018). Pemanfaatan QR-Code sebagai media pembelajaran Bahasa Asing pada Perguruan Tinggi di Indonesia. In Seminar Nasional Dies Natalis UNM. 57: 253-260.

Sari, B., K. (2017). Desain Pembelajaran Model Addie dan Implementasinya dengan Teknik Jigsaw. Jurnal Fakultas dan Ilmu Pendidikan Universitas Muhammadiyah Sidoarjo, 87-102.

Seruni, R., Munawaroh, S., Kurniadewi, F., \& Nurjayadi, M. (2019). Pengembangan modul elektronik (emodul) biokimia pada materi metabolisme lipid menggunakan Flip PDF Professional. Jurnal Tadris Kimiya, 4(1), 48-56. 
Widodo, P. B. 2006. Realibitas dan Validitas Konstruk Skala Konsep Diri Untuk Mahasiswa Indonesia. Jurnal Psikologi Universitas Di Ponegoro, 3 (1), 1-9.

Wulansari, E. W., Kantun, S., \& Suharso, P. (2018). Pengembangan E-Modul Pembelajaran Ekonomi Materi Pasar Modal Untuk Peserta didik Kelas XI IPS Man 1 Jember Tahun Ajaran 2016/2017. Jurnal Pendidikan Ekonomi: Jurnal Ilmiah Ilmu Pendidikan, Ilmu Ekonomi Dan Ilmu Sosial, 12(1), 1-7. 